\title{
Implementasi Kampung Inggris dan Manfaatnya Bagi Siswa Sekolah Menengah Atas di Kecamatan Sikur
}

\author{
Didin Hadi Saputra ${ }^{{ }^{*}}$, Masdani $^{2}$, Nasuhi $^{3}$, Mufida $^{4}$, Lalu Putra ${ }^{5}$ \\ 1, 2, 3, 4, Universitas Nahdlatul Wathan Mataram \\ 5. Pemerintah Daerah Kabupaten Lombok Timur \\ 1'didinimarc@gmail.com
}

\begin{abstract}
Abstrak
Di tengah pandemi yang melanda, kegiatan pengabdian kepada masyarakat yang bersinergi dengan pemerintah daerah mutlak diperlukan. Kegiatan pengabdian masyarakat diharapkan pula terintegrasi dengan kegiatan kepariwisataan di tingkat daerah. Tujuan pengabdian ini adalah untuk mensinergikan antara unsur tri dharma perguruan tinggi dan pemerintah daerah khususnya di tingkat kecamatan. Metode yang gunakan dalam pengabdian ini adalah metode kunjungan lapangan ke lokasi pengabdian di Kecamatan Sikur. Hasil dari pengabdian ini adalah memberikan motivasi tentang sangat pentingnya menguasai percakapan Bahasa Inggris mulai sejak dini, karena hal tersebut dapat memberikan manfaat yang sangat luas dan sangat besar dalam perjalanan karier dalam masa depan peserta pelatihan kampung Inggris. Kesimpulan dari kegiatan ini adalah perlunya memberikan motivasi terutama dengan memberikan pemahaman dan peta terhadap penguatan kegiatan kampung Inggris di masa yang akan datang, serta memerlukan dukungan dari semua pihak, baik itu dari unsur perguruan tinggi sebagai mitra strategis lokasi pengabdian maupun dari pemerintah daerah dalam hal ini pemerintah kecamatan setempat.
\end{abstract}

Kata Kunci: kampung Inggris; pemerintah daerah; Kecamatan Sikur

\section{Pendahuluan}

Salah satu dari sekian banyak tipe pembelajaran dalam pendidikan adalah usaha dalam menumbuhkan sikap berfikir kreatif, inovatif serta menyenangkan. Hal tersebut merupakan salah satu ikhtiar atau upaya dalam rangka menumbuhkan sikap mendiri dalam berkegiatan serta suatu proses dalam aktivitas belajar secara utuh serta komprehensif. Dalam proses belajar mengajar serta dalam proses mengabdikan keilmuan kepada masyarakat (Fathaddin, Sitaresmi, Kasmungin, Sriwahyuni, Widyatni, Oetomo, \& Hakim, 2020).

Sejak adanya metode belajar efektif dunia pendidikan, aktivitas para pendidik dalam menjalankan kegiatan belajar mengajar praktis menjadi lebih sederhana dan lebih mudah dari sebelumnya. Metode belajar yang asyik dan efektif dihasilkan salah satunya dari proses belajar di masyarakat dalam bentuk pengabdian kepada masyarakat. Dalam menjalankan aktivitas pengabdian, para pengabdi yang terdiri dari dosen Universitas Nahdlatul Wathan Mataram serta salah satu unsur Pemerintah Daerah tentu dapa menjadi kekuatan atau fondasi utama alam rangka menciptakan keseimbangan antara 
dunia akademik dan unsur pemerintahan (Arifianto, Susilo, Tajuddien, \& Romdonih, 2020).

Kegiatan pengabdian kepada masyarakat merupakan kegiatan rutin (wajib) yang harus dilakukan oleh seorang akademisi serta dikolaborasikan dengan unsur pemeritahah agar dapat memberikan dampak yang signifikasn serta dampak yang baik dalam upaya mengoptimalkan. Kegiatan pengabdian kepada masyarakat tidak hanya meliputi unsur akademisi saja, namun pula melibatkan peran serta unsur pemerintahan dalam sistem birokrasi yang efektif dan efisien. Menurut (Mu'arifa, 2020), esensi dari sebuah pelaksanaan pengabdian serta proses pembangunan dalam kerangka otonomi daerah dapat dilakukan dengan cara menata kembali secara bersama regulasi di daerah yang bersentuhan langsung dengan unsur masyarakat sasaran pengabdian. Dalam pelaksanaan kegiatan ini, pemerintah daerah bersama unsur perguruan tinggi harus bisa bersinergi dan bekerja bersama dalam kerangka pengabdian masyarakat dari unsur terkecil hingga terbesar. Hal ini akan berdampak kepada dihasilkannya kebijakan dalam jangka pendek maupun jangka panjang.

Salah satu upaya dari regulasi yang diterapkan oleh beberapa pemerintah bekerjasama dengan unsur atau lembaga pendidikan tinggi, yakni dalam hal ini pengabdian kepada masyarakat. Pengabdian masyarakat diharapkan pula terintegrasi dengan kegiatan kepariwisataan, seperti adanya kegiatan kunjungan di kampong Inggris tingkat Kecamatan (Azizah, 2020). Kegiatan pengabdian yang terintegrasi dengan kegiatan pariwisata, merupakan cara baru dalam menumbuhkan geliat ekonomi lokal dengan potensi yang tentunya dapat mengglobal dengan wajibnya para akademisi untuk turut serta dalam kegaiatan pengabdian tersebut (Mualifah \& Roekminiati, 2018). Namun, dengan adanya pandemic covid-19, tak menyurutkan langkah dan ikhtiar dari tim pengabadian dalam upaya mengunjungi lokasi pengabdian dengan tetap memperhatikan protokol kesehatan, yakni menggunakan masker, menjaga jarak serta mencuci tangan dengan sabun.

Salah satu cara agar mampu berbicara secara global melalui komunikasi internasional, serta untuk menghadapi tantangan pasar global, pasar bebas (secara tidak langsung) menuntut bangsa Indonesia memiliki kompetensi yang kompetitif dalam segala bidang. Indonesia tidak bisa lagi hanya mengandalkan sumber daya alam dan kemampuan fisik untuk mencapai kesejahteraan bangsanya tetapi harus lebih mengandalkan sumber daya manusia yang profesional. Salah satu syarat untuk mencapainya adalah kemampuan berbahasa Inggris, khususnya untuk berkomunikasi, baik secara lisan maupun tertulis melalui Kampung Inggris (Muslimin, 2020). Dan tentunya, penciptaan Kampung Inggris di Kecamatan Sikur merupakan salah satu program unggulan yang harus dikawal dengan baik melalui program pengabdian kepada masyarakat. Pedesaan ataupun perkampungan adalah pranata sosial yang cukup mendasar tempat terbentuknya jiwa sosial kemasyarakatan berbasis pengabdian yang bisa menentukan karakter dan daya juang seseorang, khususnya bagi remaja atau pemuda pengelola kampung Inggris yang notabenya anak muda yang berjiwa dinamis (Muslimin, 2020).

Dalam melaksanakan kegiatan pengabdian kepada masyarakat, beberapa pemerintah daerah memutuskan menerapkan kebijakan untuk meliburkan siswa kemudian mulai menerapkan metode belajar dengan sistem daring (dalam jaringan) atau online. Namun, agar semua berjalan seimbang antara daring dan luring, kegiatan pengabdian masyarakat 
kali ini mengambil lokasi di Kampung Inggris Kecamatan Sikur Lombok Timur. Dengan adanya sistem keseimbangan ini, para pengabdi yang terdiri dari unsur dosen dan pemerintah daerah di tingkat Kecamatan diharapkan mampu berkiprah dalam kegiatan pengabdian masyarakat. Kegiatan ini pula nantinya diharapkan akan mampu menjadi contoh bagi Kecamatan yang lain dalam upaya untuk mengoptimalkan kegiatan kampung Inggris. Kampung Inggris ini merupakan sebuah langkah awal kemajuan bagi pengelola pembelajaran informal di Kecamatan Sikur serta merupakan salah satu indikator penilaian bagi tim pengabdi dalam rangka mendesiminasikan ilmu pengetahuan kepada masyarakat luas serta memberikan alternatif terbaik dan termurah bagi siapa saja yang ingin mendalami percakapan bahasa Inggris dilokasi terdekat tanpa harus keluar daerah.

Di tengah pandemi yang melanda, kegiatan pengabdian kepada masyarakat yang bersinergi dengan pemerintah daerah khususnya pimpinan wilayah Kecamatan Sikur, merupakan hal yang dibutuhkan, karena terdapat kegiatan mengunjungi, dan melakukan kegiatan rutin seperti control dan monitoring pihak wilayah bekerjasama dengan unsur pengabdi dari perguruan tinggi, yakni para dosen Universitas Nahdlatul Wathan Mataram.

Untuk lebih mengoptimalkan kegiatan pengabdian masyarakat kali ini, para pengabdi dari Universitas Nahdlatul Wathan Mataram, bekerjasama dengan Pemerintah Daerah Lombok Timur tingkat Kecamatan Sikur, melakukan kegiatan turun lapangan dalam rangka meninjau, melihat dan melakukan kajian bersama dalam rangka mengoptimalkan lokasi Kampung Inggris di salah satu lokasi di Kecamatan Sikur.

Dalam kegiatan pengabdian di kampong Inggris, Bahasa Inggris merupakan Bahasa internasional yang digunakan di banyak negara termasuk di Indonesia, melihat hal tersebut, maka pimpinan daerah melalui pimpinan Kecamatan Sikur langsung merealisasikannya dengan dimunculkannya Kampung Inggris. Dengan munculnya kegiatan pengabgdian berbasis kamoung inggris ini, diharapakn mampu memberikan semangat dan gairah dalam menningkatkan mutu dan kualitas pendidikan serta pengabdian di masyarakat (Aunurrahman et al., 2020)

Tabel 1. Permasalahan yang dihadapi, solusi yang ditawarkan, dan indikator ketercapaian

\begin{tabular}{lll}
\hline Permasalahan & Solusi yang ditawarkan & Indikator \\
\hline Minat masyarakat khususnya & Pembelajaran yang serius, focus, & Masyarakat yang mengikuti \\
peserta atau siswa/i yang & dan memiliki target, namun tetap & sangat antusias serta menambah \\
mengikuti kegiatan kamung & menarik, humanis serta & percaya diri dalam berbahasa \\
Inggris & memberikan kesan yang & inggris dengan sessama peserta \\
& menyenangkan dan ceria &
\end{tabular}

\section{Metode Pelaksanaan}

Metode dalam pelaksanaan program pengabdian masyarakat dalam meninjau dampak dari implementasi kampung Inggris di Kecamatan Sikur, serta manfaat yang diberikan oleh keberadaan kampung Inggris untuk siswa dan siswi di Kecamatan Sikur adalah sebagai berikut: 


\section{Tahapan awal}

Untuk tahapan ini, kegiatan yang dilakukan oleh dosen pengabdi dari Universitas Nahdlatul Wathan Mataram adalah melakukan penyiapan data dan penyiapan untuk survey lokasi di Kecamatan Sikur Lombok Timur. Kegiatan ini dilakukak oleh tim dosen yang berjumlah empat orang, yakni dari Fakultas Ilmu Administrasi serta Fakultas Agama Islam, serta satu dari pimpinan wilayah Kecamatan Sikur. Hal ini dibutuhkan oleh tim pengabdi untuk dapat memetakan situasi awal dari lokasi pengabdian kepada masyarakat berbasis pengembangan mutu dan kualitas pendidikan, khususnya di Kecamatan Sikur.

Rencana program pengabdian kepada masyarakat disampaikan kepada peserta yang mengikuti kegiatan pengabdian di Kecamatan Sikur dengan target utama peserta kampung Inggris, yakni siswa menengah atas atau SMA. Program pengabdian ini disampaikan di wilayah Kecamatan Sikur Lombok Timur.

Selain itu, seluruh peralatan pendukung program pengabdian serta formula atau strategi pelaksanaan program dipersiapkan secara bertahap di Kecamatan Sikur Lombok Timur.

\section{Tahapan pelaksanaan}

Strategi dan pelaksanaan pengabdian masyarakat di kecamatan Sikur yang dilakukan oleh ti pengabdi menerapkan pola atau metode manajemen kemitraan atau pola bina masyarakat, yakni kegiatan pengabdian yang dilakukan akan memberikan dampak atau perubahan yang signifikan dalam perubahan mutu dan kualitas pelaksanaan dari implementasi kampung Inggris di Kecamatan Sikur. Kegiatan ini juga diharapkan memberikan dampak positif sesuai dengan tujuan pengabdian masyarakat.

Tahapan pelaksanaan terlaksana atas adanya komunikasi serta sinergi yang kuat serta utuh antar pihak pengabdi (dengan diawali oleh survey lokasi) dengan mitra terkait, yakni keaktifan, peran serta kontribusi pengelola kampung Inggris di Kecamatan Sikur.

Dalam proses pengabdian masyarakat akan dilakukan terus koordinasi terkait progress dari pengabdian masyarakat ini.

\section{Tahap monitoring dan evaluasi}

Pada tahap ini akan dilakukan monitoring terkait dengan jumlah peserta kampung Inggris di Kecamatan Sikur, proses ini dilakukan dalam jangka waktu 4 sampai dengan 5 bulan secara rutin dalam upaya mendapatkan kualitas belajar yang optimal.

Metode evaluasi yang digunakan yaitu metode kegiatan pengabdian di lapangan, yakni dengan mendalami aktivitas kampung Inggris secara komprehensif dan secara rutin buka hanya ketika melakukan pengabdian, tetapi juga secara sustainable atau berkelanjutan.

\section{Tahap pelaporan}

Pada tahapan ini, dilaporkan semua proses rangkaian atau tahapan kegiatan pengabdian di wilayah Kecamatan Sikur dan output dari kegiatan ini, yaitu, terciptanya kampung Inggris yang bermutu dan berkualitas. 


\section{Hasil dan Pembahasan}

Tahap pengabdian masyarakat ini dimulai dengan berkoordinasi dengan beberapa pihak, yakni para pimpinan wilayah serta para pengabdi, yakni dosen Universitas Nahdlatul Wathan Mataram. Kegiatan ini dilaksanakan sebanyak 2 kali, yakni tanggal 5 sampai 6 April 2021. Pertemuan pertama membahas masalah pemetaan kegiatan bersama unsur dosen serta mahasiswa peserta pengabdian dan pimpinan Kecamatan Sikur. Pemetaan kegiatan diperlukan untuk mengetahui jenis kegiatan yang akan dilaksanakan di era pandemic dengan tetap menerapkan protokol kesehatan dengan ketat.

Oleh sebab itu, tim pengabdi bersama para mitra pendiri kampung Inggris dan pihak Kecamatan sepakat mengadakan kunjungan serta memberikan kegiatan berupa pemberian motivasi dalam menempuh kegiatan belajar di kampung Inggris yang dilakukan oleh tim dari Universitas Nahdlatul Wathan Mataram. Tim pengabdi bersama para pengelola sekitar lokasi pelatihan atau lokasi kampung Inggris memberikan motivasi terkait pendidikan global. Salah satu tim pengabdi dari Fakultas Agama Islam Universitas Nahdlatul Wathan Mataram memberikan motivasi tentang sangat pentingnya menguasai percakapan bahasa Inggris mulai sejak dini, karena hal tersebut dapat memberikan manfaat yang sangat luas dan sangat besar dalam perjalanan karier dalam masa depan peserta pelatihan kampung Inggris. Selama kegiatan pengabdian kepada masyarakat, tim pengabdian yang berjumlah 5 (lima) orang, secara bergantian menyampaikan materi dalam dua bahasa, yakni English dan Indonesia. Adapun materi yang menggunakan bahasa Indonesia, dibantu penerjemahaannya oleh salah satu tim pengabdian yakni dosen Fakultas Ilmu Agama Islam.
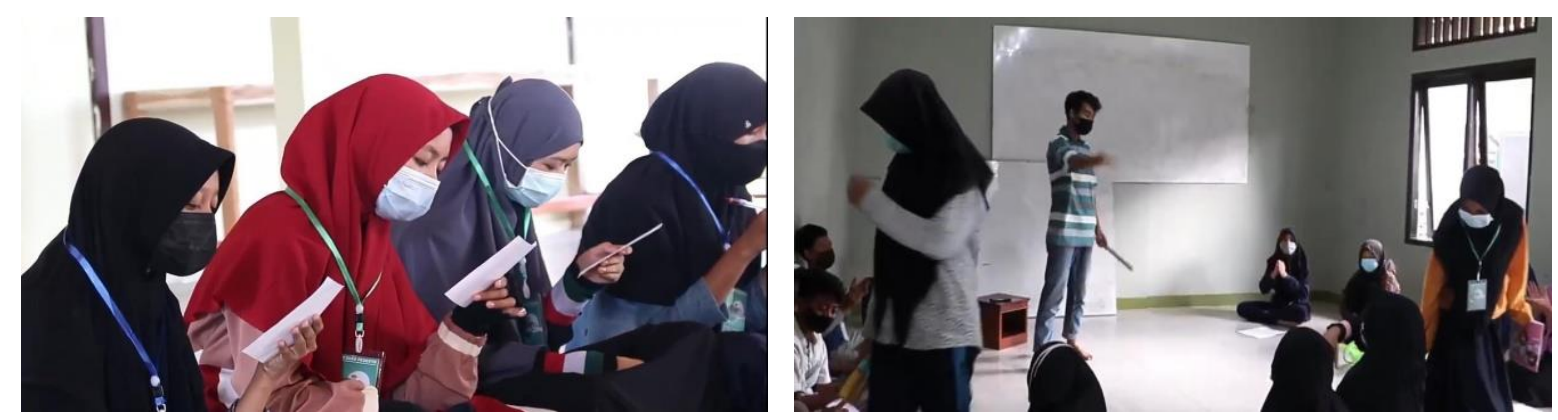

Gambar 1. Kegiatan belajar kampung Inggris

Oleh karena itu, tim PKM selama 4 pertemuan dilakukan dengan memberikan pembelajaran yang tidak hanya serius mengingat para peserta didik juga sudah cukup diberi banyak pelajaran di sekolah, namun juga menarik dan menyenangkan agar mereka dapat betah dan perhatian ketika mereka belajar Bahasa Inggris. Satu hal lagi, pembelajaran di tiap sesi hanya menggunakan materi yang sedikit sekali. Kegiatan pengabdian kepada masyarakat ini adalah salah satu bentuk usaha untuk menyebarluaskan atau untuk mendesimenasikan ilmu pengetahuan secara menyeluruh serta komprehensif kepada khalayak atau masyarakat. Karena sejatinya ilmu pengetahuan adalah fondasi kokoh untuk meraih masa depan yang lebih baik. Kegiatan pengabdian yang dilakukan telah menghasilkan output atau hasil dari ikhtiar awal pendirian kampung Inggris itu sendiri, yakni makin banyaknya masyarakat, terutama peserta didik yang ingin belajar langsung ke sumber kampung Inggris, yakni Kecamatan 
Sikur. Para calon peserta pelatihan kampung Inggris berpendapat bahwa daripada menempuh perjalanan jarak jauh ke kampung Inggris di daerah lain, lebih baik berlatih di tempat sendiri saja, karena hasilnya sama, dan bahkan jauh lebih nyaman mereka menjalani pelatihan di daerah sendiri.

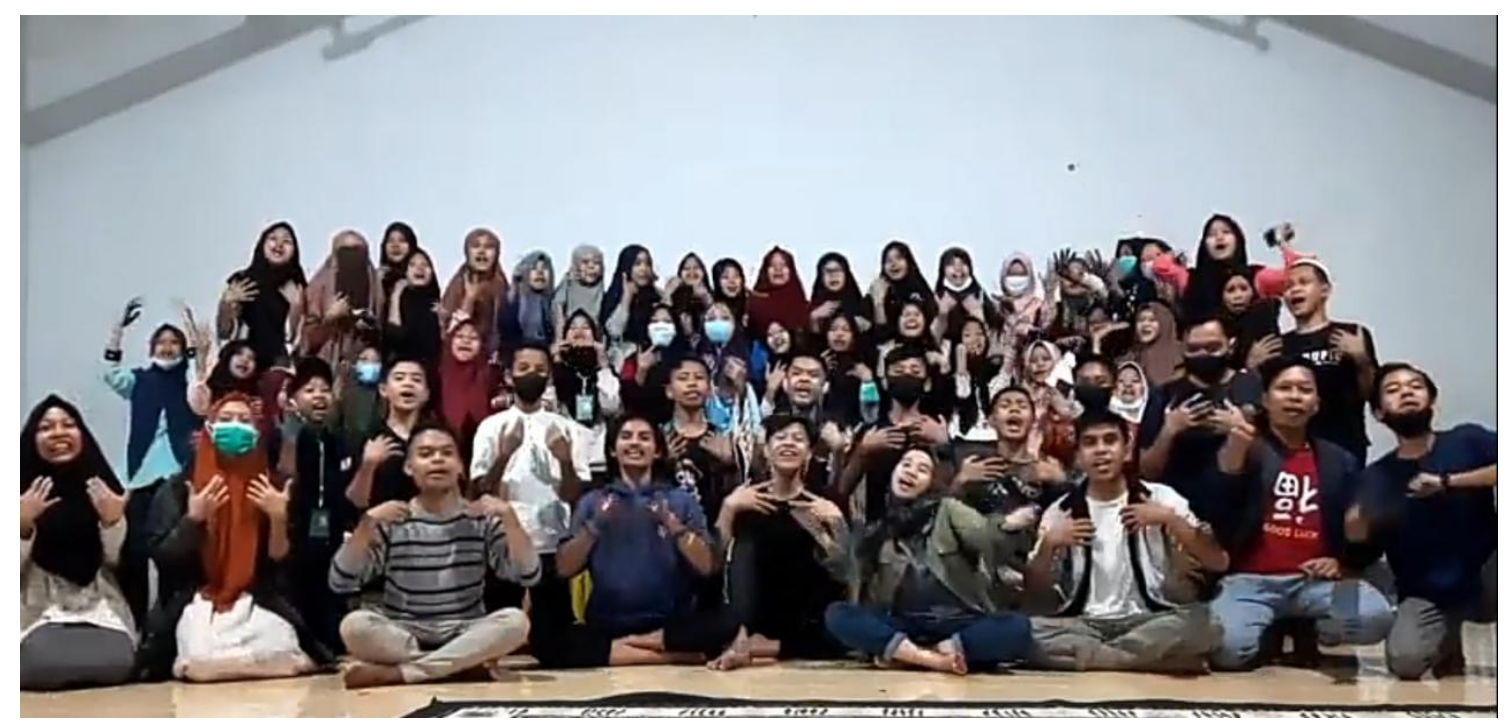

Gambar 2. Bersama peserta kampung Inggris

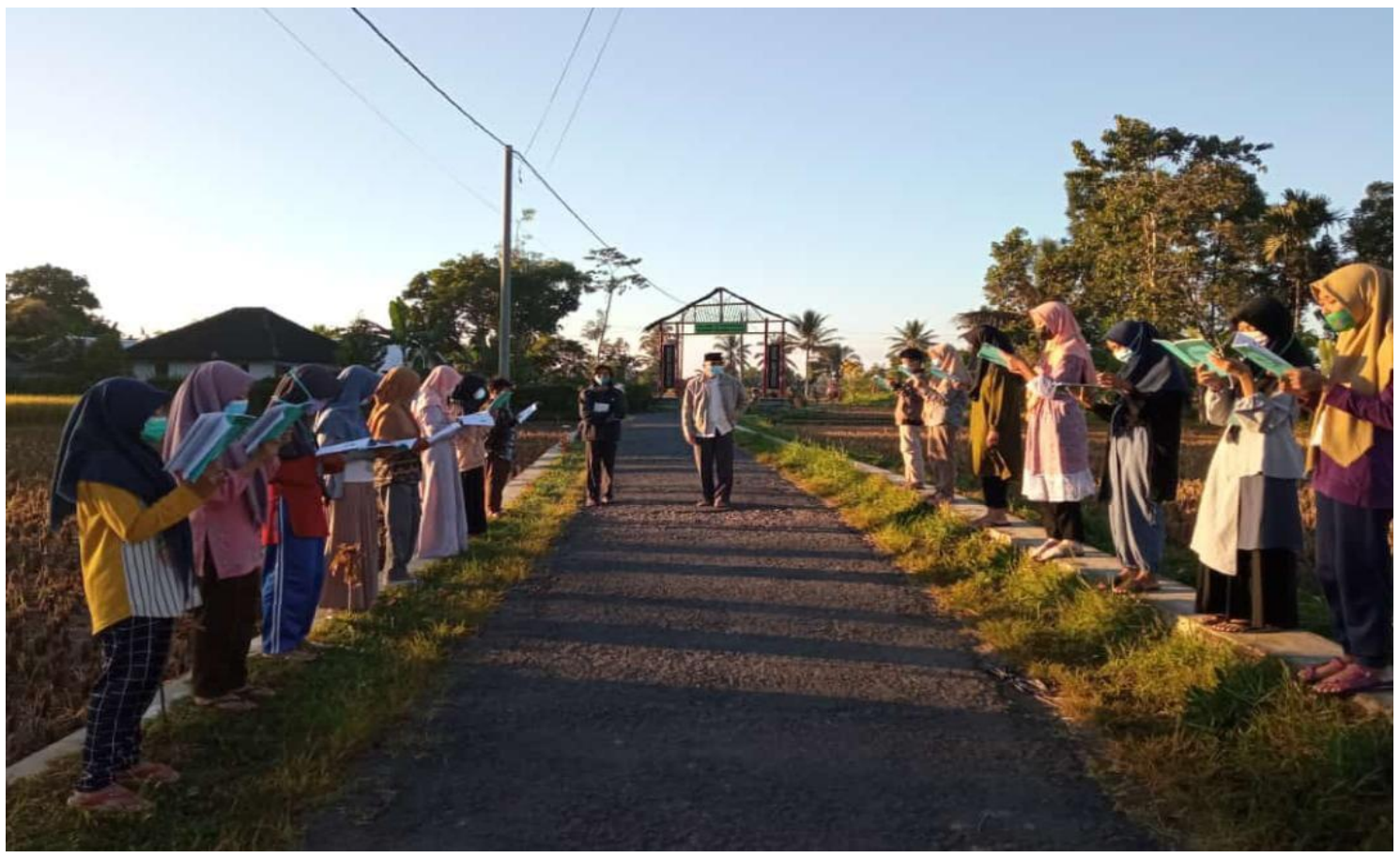

Gambar 3. Kegiatan kunjungan bersama pimpinan kecamatan

\section{Kesimpulan}

Dalam kegiatan pengabdian di kampung Inggris Kecamatan Sikur, tim pengabdi bersama unsur pimpinan kecamatan memberikan memberikan motivasi terutama dengan memberikan pemahaman dan peta terhadap penguatan kegiatan kampung Inggris di masa yang akan datang. Adapun kegiatan kampung Inggris yang telah berjalan, memerlukan dukungan dari semua pihak, baik itu dari unsur perguruan tinggi sebagai 
mitra strategis lokasi pengabdian maupun dari pemerintah daerah sendiri, yakni khususnya pemerintah daerah Kecamatan Sikur.

\section{Ucapan Terimakasih}

Setelah menyelesaikan kegiatan pengabdian kepada masyarakat, tim pengabdian bersama pimpinan wilayah kecamatan memberikan masukan serta saran yang bersifat membangun motivasi, yakni terus jalin komunikasi dengan seluruh unsur masyarakat secara komprehensif serta tetap menjaga kualitas serta mutu dari output kampung Inggris yang telah berjalan. Ucapan terima kasih kami ucapkan kepada tim pengabdi dan unsur pimpinan daerah Kecamatan Sikur yang telah mendukung kegiatan pengabdian ini.

\section{Referensi}

Arifianto, C., Susilo, A., Mutawali, M., Tahuddien, R., \& Romdonih, F. (2020). Peningkatan Kapabilitas Teknologi Dalam Menghadapi Era Disrupsi Pada Generasi Milenial Melalui Webinar. Bakti Banua: Jurnal Pengabdian Kepada Masyarakat, 1(2), 89-94. https://doi.org/10.35130/bbjm.v1i2.142

Aunurrahman, A., Musa, M., Rustam, R., Kusumaningsih, C., Susanti, E., Kurniawati, T., Irwan, D., Wiyanti, S., Sahrawi, S., Hafis, M., Anita, F., Putra, M., Astuti, D., Sari, D., Syahadati, E., Darajat, A., \& Ramadhiyanti, Y. (2021). Membangun Minat Peserta Didik Kampung Inggris Parit Baru Dalam Belajar Bahasa Inggris. Gervasi: Jurnal Pengabdian kepada Masyarakat, 4(2), 282-292. https://doi.org/10.31571/gervasi.v4i2.1907

Azizah, A. (2020). Pelatihan Pembelajaran Daring di masa Pandemi Covid-19 Untuk GuruGuru SD Negeri 3 Melayu Muara Teweh. Bakti Banua: Jurnal Pengabdian Kepada Masyarakat, 1(2), 78-83. https://doi.org/10.35130/bbjm.v1i2.152

Fathaddin, M., Sitaresmi, R., Kasmungin, S., Sriwahyuni, M., Widyatni, H., Oetomo, H., \& Hakim, D. (2020). Pembelajaran Aktif, Kreatif, Efektif, Dan Menyenangkan Untuk Siswa Siswi SMK Migas Cibinong. Bakti Banua: Jurnal Pengabdian Kepada Masyarakat, 1(2), 73-77. https://doi.org/10.35130/bbjm.v1i2.129

Mu'arifa, N. (2020). "Kampung Inggris" dan Implikasinya Terhadap Sosial Ekonomi Masyarakat (Studi Pada Dusun Singgahan, Desa Pelem dan Desa Tulungrejo, Pare, Kabupaten Kediri). Jurnal Ilmiah Mahasiswa FEB, 8(1), 1-94.

Mualifah, N., \& Roekminiati, S. (2018). Pemberdayaan Masyarakat Kampung Inggris Sebagai Destinasi Wisata Edukasi di Kecamatan Pare Kabupaten Kediri. Jurnal Ilmiah Manajemen Publik dan Kebijakan Sosial, 2(1), 168-182. https://doi.org/10.25139/jmnegara.v2i1.1069

Muslimin, A. I. (2020). Pemberdayaan masyarakat untuk merintis kampung Inggris di Desa Kalipakem Kecamatan Donomulyo Kabupaten Malang. Transformasi: Jurnal Pengabdian Masyarakat, 16(1), 27-42.

https://doi.org/10.20414/transformasi.v16i1.2144 